Tarih Kültür ve Sanat Araştırmaları Dergisi (ISSN: 2147-0626)

DOI: 10.7596/taksad.v1i3.142

\title{
Prof. Dr. Zeki ARSLANTÜRK’ le Hayatı ve Çalışmaları Üzerine Söyleşi
}

\section{Uğur GÖZEL - Halit GÜRLEYIK*}

\section{Özet}

3. Ulusal Sosyoloji Çalıştayı bu sene Karabük Üniversitesi Sosyoloji Bölümü tarafından düzenlendi. Çalıştayın katılımcılarından Marmara Üniversitesi İlahiyat Fakültesi Din Sosyolojisi Anabilim Dalı Başkanı Prof. Dr. Zeki ARSLANTÜRK' le bir söyleşi düzenledik. Prof. Dr. Zeki ARSLANTÜRK' le hayatı ve çalışmaları üzerine yaptığımız bu keyifli sohbette, özellikle hocamızın etkilendiği önemli şahsiyetlerle ilgili hatıraları, tam bir yol gösterici rehber niteliğinde.

Fikri dünyasının temelleri çocukluk yıllarına dayanır Zeki ARSLANTÜRK Hoca'nın. İstanbul'a gelişleri, iki lise diplomasıyla iki üniversiteyi biden aynı anda okuması ayrı bir tecrübedir. Çalkantılı yıllardaki üniversite hatıraları, arkadaşları, hocaları ve üstatları, akademik hayatında onun rehberleri, yol göstericileri, adeta çalışma azmini güçlendirici birer ivme noktaları olmuşlardır.

Ziyaeddin Fahri Fındıkoğlu, Mehmet Eröz, Cahit Tanyol, Amiran Kurtkan, Orhan Türkdoğan, Nurettin Topçu, Osman Yüksel Serdengeçti, hocamızın hatıralarında yer alan önemli şahsiyetlerden sadece bir kısmı. Önemli dönüm noktaları ve ibretlik bir hayat hikayesi.

Anahtar Kelimeler: Zeki Arslantürk, Ziyaeddin Fahri Fındıkoğlu, Mehmet Eröz, Cahit Tanyol, Amiran Kurtkan, Orhan Türkdoğan, Nurettin Topçu, Osman Yüksel Serdengeçti.

\footnotetext{
* Karabük Üniversitesi Sosyoloji Bölümü
} 


\title{
Interview on the Life and Works of Prof. Dr. Zeki ARSLANTÜRK
}

\begin{abstract}
The Third National Sociology Workshop has been organised by Sociology Depertment of Karabük University. We have also organised a conversation with Professor Zeki Arslantürk who is one of the participants of the workshop. His memories and ideas are such a guidance for us.

The (basics) fundamentals of his thoughts emerges from his childhood years. Professor's memories which belong to university, friends and expert teachers have been his guide and strengthen point of his determination.

Some of the important people who have taken considerable place in his life are Ziyaeddin Fahri Findıkoğlu, Mehmet Er Özbey, Cahit Tanyol, Amiran Kurtkan, Orhan Türkdoğan, Nurettin Topçu, Osman Yüksel Serdengeçti .

Keywords: Zeki Arslantürk, Ziyaeddin Fahri Fındıkoğlu, Mehmet Eröz, Cahit Tanyol, Amiran Kurtkan, Orhan Türkdoğan, Nurettin Topçu, Osman Yüksel Serdengeçti.
\end{abstract}

- Muhterem hocam! Öncelikle söyleşimiz için bize zaman ayırdığınız için teşekkürlerimizi sunuyoruz. Dün üçüncüsünü üniversitemizde yaptığımız çalıştay vesilesiyle Karabük'e geldiniz. Bu firsattan istifade biz de sizi daha yakından tanımak istedik. Sizce de uygunsa söyleşimize hayat hikâyenizle başlayalım.

- Prof. Dr. Zeki Arslantürk: Tabi tabi nasıl isterseniz.

- 1947 Trabzon ili Of ilçesi doğumlusunuz.

- Prof. Dr. Zeki Arslantürk: Evet. 1947 yılı Eylül ayında Trabzon’un Of İlçesi Geçitli köyünde doğdum. İlkokul dördüncü sınıf dâhil memleketimde okudum. Babaannemin rahatsızlığg nedeniyle 1960 yılında ailece İstanbul'a taşındık ve bu vesileyle de İstanbul'a yerleştik. Babam inşaat müteahhidiydi. Eğitimime kaldığım yerden İstanbul'da devam ettim.

- İlkokuldan sonra İmam-Hatip Lisesine başladınız.

- Prof. Dr. Zeki Arslantürk: Babam rahmetli abimle ikimizin okumasını çok isterdi ama ben okuyabildim sadece. İlkokul bitince, sınavla öğrenci alan İmam-Hatip okuluna gittim. 1967-68 döneminde İmam-Hatip'i, 1973-74 döneminde de üniversiteyi bitirdim.

İmam-Hatip Lisesinden sonra fark derslerini vererek Eyüp Lisesinden lise diplomasını aldım. Bu diplomaların birini Fakülteye birini de Yüksek İslam Enstitüsüne vermek suretiyle iki üniversitede birden okudum. 
- Farklı diplomalarla iki farklı üniversiteyi aynı anda mı okudunuz?

- Prof. Dr. Zeki Arslantürk: Zaten bizim dönemimizde İmam-Hatipliler arasında bir modaydı bu. Çünkü aynen o dönemde İmam-Hatiplilerin üniversitede istedikleri bölümlere girememeleri söz konusu idi.

\section{-O zamanlarda Sadece Yüksek İslam Enstitüsüne mi gidebiliyordunuz?}

- Prof. Dr. Zeki Arslantürk: Evet, sadece Yüksek İslam’a gidebiliyorduk ama bizim bir hakkımız vardı. Fark derslerini vermek suretiyle lise diploması alabiliyorduk. O dönemlerde İmam-Hatip mezunlarının hemen hepsi aynı yöntemle lise diploması aldılar ve farklı üniversitelere kayıt yaptırdılar.

\section{biraktı?}

- Lise yıllarından bahseder misiniz biraz? O dönem hayat çizginizde nasıl etkiler

- Prof. Dr. Zeki Arslantürk: Beni şu anda nasıl tarif ederler: Zeki Arslantürk Hoca Türk İslam ülküsüne bağlı bir hoca. Şimdi bir Türklük tarafına bağlılığın bir de İslam tarafına bağlılığın iki kanalı var. Türklük tarafına bağlılığımla ilgili bir olay anlatayım:

İlkokul dördüncü sınıftayız. Öğretmenimiz bir gün sınıfa girdi ve "Çocuklar bugün size Türk bayrağının doğuşunu anlatacağım.” dedi. Biz de çocuğuz işte, dinliyoruz. "Türk bayrağı saf kandan ibarettir. Bu bayrak Türk kanıyla sulanmıştır.” dedi. Malazgirt'teki olayı anlattı uzun uzadıya. Benim o dersten aklımda kalan, bayrağın kandan yapıldığıydı. Çocuğuz işte, akşam eve geldiğimizde birinci sınıfa giden kardeşime, "Bak Muammer bize hocamız Türk bayrağının doğuşunu anlattı.” dedim ve "Gel seninle bir bayrak yapalım.” dedim. O gün çocuk aklımızla kendi kanımızdan bayrak yapmaya çalıştık ama beceremedik. Ama Türk bayrağının doğuşuyla ilgili başlayan bu hikaye bende bir bayrak ve vatan bilinci doğurdu. Burada çocuğa verilen ilk bilginin de önemini hatırlatmak gerekir.

- Boş sayfaya öğretmeniniz güzelce işlemiş bayrak sevgisini ve o da kalıcı olmuş anlaşılan.

- Prof. Dr. Zeki Arslantürk: Aynen öyle, kalıcı oldu ve ondan sonra Türk bayrağı kavramı yer etti. Kanalın birisi buradan geliyor.

Bir diğeri: Ben bu günüme kadar bilerek namazımı geçirmiş değilim. Tabi uyku hastalık falan, saymıyorum. Çocukluğumdan beri orucumu ve namazımı ihmal etmedim. Hayatımda da iki şey yapmadım. Ağzıma bir damla olsun içki koymadım ve kimsenin namusuna bakmadım. Bunun dışında birçok şey yaptım; ama Allah'ın huzuruna üç şeyle çıkacağım: Birisi bu son söylediğim iki şey, bir diğeri de, 1982 yılında Erzurum'da başörtüsünden dolayı yediğim ceza. Sınıfımda başörtülü öğrenci bulunması sebebiyle, dekanın yaptığı kontrolde yakalandık. Hemen cezayı yedik. Türkiye'de üniversite hocası olarak başörtüsü sebebiyle ceza yiyen tek kişi herhalde benim. Elime soruşturma evrakı tutuşturuldu ve uyarı cezasını verdiler hemen. Öbür dünyaya bir bunlarla gideceğim bir de eserlerimle. 
Eserlerimde eğer Allah'ın hoşuna gitmeyecek bir düşünce serdetmiş isem Allah hatalarımı affetsin. Benim bütün duam "Ya Rabbi! Tövbesini nasip etmeyeceğin günahı bana işletme.” Bütün duam budur. Tövbe ettiğin zaman günah siliniyor zaten; ama bir de tövbesini nasip etmeyebilir. Bir de Hz. Ebu Bekir' in duası var, nedir o? "Ya Rabbi! Hakkı hak olarak, batılı da batıl olarak bana göster. Hakkı yapmayı, batıldan da sakınmayı bana öğret."

Nereden geliyor bunlar diye düşündügümde, burada anmadan geçmeyelim, Amiran Kurtkan hocamızdan geliyor. 'Mutlak doğru, Allah'ın doğrusudur. Kur' an Allah'ın kitabıdır. Mutlak doğru Kur'an’dır. Bilim ne kadar gelişirse gelişsin Kur'an’1 yanlışlayamaz. Gerçek din bilime meydan okuyan dindir."

Bilim ancak bir yere kadar gelebilir. Ötesini göremez. O yüzden bilimin dini doğrulaması konusunda sıkıntı olabilir. Yanlışlama noktasından hareket ettiğin vakit söylenenin, var olanın yanlışlamasına gidilecek ki, Kur'an'ı yanlışlaması mümkün değildir.

- Lise bitti, ardından hem Yüksek İslam Enstitüsüne hem de İstanbul Üniversitesi Sosyoloji bölümüne başladınız.

- Prof. Dr. Zeki Arslantürk: İki okul birden, sabah yediyi beş geçe Fatih'ten yirmi sekiz numaraya bin Üsküdar'a geç, oradan Bağlarbaşı'na çık, sekizde derse gir. Dersten hemen sonra bir de otobüse yetiş, Kadıköy veya Üsküdar'a in, oradan hemen üniversiteye gel, anarşi boykotu yoksa derse girersin, çoğunlukla derse giremezdik ya o ayrı mevzu. Sonra eve gelip yemeği yiyip hemen sekizde tekrar derse git. Bir ev tutmuştuk, orada yedi sekiz sene Emin Saraç hocayla ders yaptık. Hafta sonu yurtlara giderdik, namaz kıldırıp dini eğitim vermeye. Üniversite hayatımız böyle koşuşturmayla geçti.

- Peki Sosyolojiyi seçme nedeniniz neydi?

- Prof. Dr. Zeki Arslantürk: Bayraktar Bayraklı, İzzet Er, Yaşar Erol biz İmamHatip’ten aynı takımız. Nereye gidelim diye düşündük, Felsefeyi gözümüz kesmedi. Bizim Felsefe hocamız vard1, Turgut Ulusoy rahmetlik, Erzurumlu İbrahim Hakkı Hazretleri' nin Marifetname'sini çeviren kişidir kendisi, o bizi heveslendirdi. Hepimizin puanı epey yüksekti. Hukuk falan birçok yere girebiliyorduk. O zaman ön kayıt vardı. Puanlar ilan ediliyordu, gidip müracaat ediyordunuz, puanınız tutarsa başlıyordunuz üniversiteye. Biz de karar verdik sosyolog olacağız diye. Biz, Türklük ve İslam kavramının benliğinde netleştiği dört gençtik.

O zamanlar susamıştık bilgiye. Bilenler arasında kimler vardı? Nurettin Topçu hoca vardı. Hocayla sekiz seneye yakın Cuma günleri Sultan Ahmet'teki yerinde toplantılar yaptık. Cemil Meriç'in, bugün Fethi Paşa Korusu denilen yerdeki yerine giderdik. O dönemde ne varsa, ne bulursak giderdik bir şeyler öğrenmeye.

Osman Yüksel abimiz vardı, Serdengeçti. Yüz on dört yıl mahkûmiyet kararı var. O ara da seçimler var. Bir yerlerden milletvekili seçilirse hapisten kurtulacak. Erbakan Hocanın o zaman meclise girmesi garanti gibi. Serdengeçti ve birkaç kişi partiden istifa edip Erbakan Hoca'nın partisine geçiyorlar, milletvekili olmak için. Hocaya diyorlar "Hocam bize bir yer göster de gidelim, çalışmalarımıza başlayalım" Hoca da tabi biraz niyetsiz galiba "Evet Osman Bey kardeşim, siz bir yörenin milletvekili olamazsınız, siz bütün Türkiye'nin 
milletvekilisiniz." Bir süre sonra tekrar ısrar ediyorlar. Isparta ili ikinci sirayı veriyor Osman Bey’e. "Hoca bizi Isparta’ ya değil Iskartaya gönderdi” der eğlenirdi.

Bir gün yine karşılaştık. "Ne o Zeki” dedi "Selamsız sabahsız geçip gidiyorsun." "Ne selam vereceğim abi” dedim. "En son gidecek adam sendin, sen de birakıp gittin bizi” diye takıldım. "Yazacağım bunları Zeki, yazacağım" dedi. Ne yazacaksın abi dedim. "Hareketten selamete, selametten felakete diye yazacağım" dedi.

Bunları neden anlatıyorum? Said'i Nursi, Nurettin Topçu, Osman Yüksel Serdengeçti, Nihal Atsız. Bunların mirasını yedik bitirdik. Onun için bugün sıkıntıdayız. O mirası devam ettiremedik.

- Niye devam ettiremedik?

- Prof. Dr. Zeki Arslantürk: Bu saydıklarımın hepsinde isyan ahlâkı var. Haksızlığa karşı isyan edebiliyorlardı, haksızlığa karşı dik durabiliyorlardı. Neye mâl olursa olsun.

Mesela, bir şey daha anlatayım. Bir Fakir Baykurt vardı, romanı var "Muhammetçik" diye. Hazreti peygambere hakaret. Mehmetçik yazsa tamam, Muhammetçik yazmıs. Necip Fazıl: "Bir on sene daha içeride yatmaya değer, bu adama yazacağım." diyor, yazıyor ve yatıyor bildiğim kadarıyla da. İşte o büyük insanların zihin dünyasını şekillendirdiği bir insanım.

O dönemde üniversiteye ya devam etmeyecektiniz; ya da ülkücü olacaktınız ki korunasınız. Bazı arkadaşlarımız bıraktı okulu; ama biz devam ettik. Hem okuduk hem mücadelemize devam ettik, hem de Allah rızası için görev icra ettik. İnşallah öyledir.

Türkiye de ülkücüler olmasa idi bugün Türkiye Rusya'nın eyaleti idi. Çünkü Rusya'nın tek ideali vardı, sıcak denizlere inmek. Türkiye bunun için en ideal yoldu. Eğer Türkiye düşseydi komünizm de gitmezdi. Türkiye' yi düşürememe nedeni o beş bin tane ülkücü şehittir.

İlk şehitlerden biri benim arkadaşımdı, Yusuf İmamoğlu. Coğrafyada okuyordu. Allah rahmet eylesin.

- Sebep neydi?

- Prof. Dr. Zeki Arslantürk: O zamanlara baktığınızda, Anadolu'dan gelme öğretim görevlisi veya yönetici pek yok. Aristokrat kesimin elinde her yer. Mesela biz derse girerdik, Muzaffer Sencer Hoca "Karl Marks der ki” diye başlardı söze. Ses çıkaramazdık tabi. Zaman zaman “Arap'ın çöl bedevisi” diye, "Kur'an falandı” diye başladılar mı ateşlemeyi yaparlardı. Bunlara ilk karşı çıkan Yusuf'tu. Tabi onu da kan revan içinde şehit ettiler. Ardından gruplaşmalar, çatışmalar devam etti gitti.

- Şimdi biz bu filmlerde dizilerde falan görüyoruz. Ülkücüler beline silahı takmış, önüne gelene çatan, canını sıkanı vurup indiren kişiler olarak ekrana yansıyor.

- Prof. Dr. Zeki Arslantürk: Haa! Sen benim Allah'ıma peygamberime küfret, Arap bedevisi de, falanca de, benim sesim çıkmasın. Bizim o dönemde, Allah biliyor, bu tür kırmızı çizgilerimizi ihlal eden olmadığı sürece hiçbir şekilde karşı çıkılmadı. 
O dönem Aydınlık dergisi yayınlanırdı, bu gün de çıkıyor. Aydınlık dergisinde hedef gösterilirdi, dergide ismi geçen, resmi yayımlanan bütün ülkücüler şehit edildi. Alenen hedef gösterilirdi.

- Konu eğitim hayatınızdan açılmışken sorayım hemen, hocalarınızdan, sizi etkileyen öğretmenlerinizden bahseder misiniz bize biraz?

- Prof. Dr. Zeki Arslantürk: Benim hayatımda tesiri olan hocaların arasında ilk başta söyleyebileceğim, Fatih Camiinde Gümülcineli Mustafa Efendi. Ona bütün hayatımın hocası diyebilirim. İlk tanışmamız dayakla olmuştur. İmam-Hatip beş veya altıncı sınıftayım. Fatih Camiinin şadırvanında abdest alıyorum. Çocuklar var, suyla falan oynuyorlar. O benim de oynadığımı zannederek, onlara da bana da dayağı attı. Tabi ben tanımadım. Kim olduğunu bilmiyorum. Eve geldim, babama anlattım, adamı tarif ettim. Babam birden doğruldu: "O Gümülcineli Mustafa Efendidir. Hemen git yarın elini öp.” dedi. Ertesi gün gittim, hocanın elini öptüm, olayı anlattım.

Hoca on dört türlü yazı yazardı, Hüsnü hat. Bir gün camiye gittim, hoca bir kenarda oturmuş, elinde kâğıtlara güzel sözler yazıyor. Arapça okuyabilen alıyor okuyor. Ben de gittim aldım elime, okudum bir tanesini. "Men azübe lisanuhu, kesüre ihvanuhu - kimin dili tatlıysa seveni çok olur." okuduğumu görünce hoca şaşırdı tabi. Orda sopası vardı, aldı eline, bir vurdu, bir daha vurdu. Tabi ben duruyorum bir şey demeden. "Uzat enseni" dedi. Uzattım ensemi, şöyle elini bombeli yaptı, avuç içi boş, enseme vurdu. Avcunun içini yuvarlak bombeli yaptı ki acımasın diye.

\section{- Yani maksat dövmek değil, can yakmak değil.}

- Prof. Dr. Zeki Arslantürk: Tabi tabi can yakmak değil. Sonra "Kalk git." dedi. Kalktım, müezzin mahfilinin önünde iki makam daha vardır: Biri Mehmet Akif' in makamıdır, birisi de Gazi Osman Paşa'nın makamıdır. Halılar değişinceye kadar her ikisinin makamının diz yerleri belliydi. Ben Gazi Osman Paşanın makamında durdum biraz, ondan sonra gittim yanına. Uzat enseni dedi, gene bir vurdu, ondan sonra da öptü. "Ah!" dedi, "Sizi gidi ahir zaman uleması." Şu anda yaşayanların kolay kolay anlayabilecekleri bir şey değil bu. O öpücüğü hâlâ buradadır -kalbini göstererek. Hayat hep o öpücük üzerine kuruludur.

Ondan sonra orada, Fatih Camii' nde ders almaya başladık. Medrese dersleri.

Bir gün yine derste def, davul ve zurna çalmanın hükmü konuşuldu. "Def helal, davulun büyük tokmağı helal, küçük çubuğu haramdır.” dedi. Dedim ki Emin Saraç Hoca' ya: "Arapların defiyle göbek atılıyor, benim kemençemle de oynanıyor, o helal ise bizim kemençemiz neden haram?” dedi ki "Zeki, seddi zerayi diye bir şey var.” zararlı şeylere set çekme. "Kapıyı aralama ardına kadar açılır. Biz bunun yolunu açarsak memlekette herkes kemençeci olur, ama birileri kemençe çalacak Allah da onları affedecek."

Hayatımda beni etkileyen hocalar arasında, Ziyaeddin Fahri Fındıkoğlu Hoca'yı söyleyebilirim. Ondan sonra rahmetli Mehmet Eröz Bey, onu anlatmak kelimelere sığacak bir olay değil. Pek fazla tanınmıyor belki; ama gerçek bir ağabey, gerçek bir büyük, gerçek bir vatanperver, gerçek Türk İslam ülküsüne sahip kişilerden bir tanesi. Türk toplumunu heybeler 
üstünde Anadolu'yu geze geze öğrenen, bilen, araştıran bir kişi. Anadolu'da Yörük kültürü Hoca'nın çalışmasıdır. Benim tezimde de hocamın etkisi var. Doktora tezim Naima' ya Göre Osmanlı Devletinin çöküş sebepleri.

Doktora imtihanına girdim. İmtihanı kazandım. Cahit Tanyol Hoca doktora hocamdır. “Naima’ yı araştıracaksın” dedi. Oradan Merhmet Eröz Hoca’ya gittim. İstanbul Ü. İktisat Fakültesi' nde. Tezimin konusunu söyledim. Karşısında Amiran Kurtkan Hoca oturuyor. Onu işaret etti. "Amiran Hanım! Bak Zeki'nin bir problemi var çözer misin?” dedi. Problem demedi onu yanlış söyledim. Meselesi var, dedi. İkisi de yabancı kelime kullanmayı sevmezlerdi. Çünkü her ikisi de Fındıkoğlu Hoca'nın talebesi. Fındıkoğlu Hoca'nın meşhur bir sözü var, böyle durumlarda söylenir hep. Bu "sel" ve "sal” takılarıyla ilgili. "Ben bu aziz milleti sallara bindirip sellerden geçiremem.” derdi. Fındıkoğlu Hoca'nın ruhu muazzep olmasın diye uydurma veya yabancı kelime kullanmazlardı.

Fındıkoğlu Hoca Orhan Türkdoğan Hoca'nın doktora hocası. Türkdoğan Hoca Erzurum'da asistan. Tezini göstermek için İstanbul'a geliyor. Hocanın evine gidiyor. Fındıkoğlu Hoca'nın hanımı açıyor kapıyı. O sıra kahvaltı yapıyorlarmış. Türkdoğan Hoca' yı da buyur ediyorlar. Oturuyorlar beraber kahvaltıya. O ara Fındıkoğlu hoca tezi karıştırmaya başlıyor. Türkdoğan Hoca tezde "terbiye" yerine "eğitim" kelimesini kullanmış. Hocanın suratı değişiyor tabi bunu görünce. Sonra hanımına sesleniyor, "Hanım, bana bir eğitimli çorba getir.” diye. Eğitimli çorba olur mu? Terbiyeli çorba olur. Türkdoğan Hoca anlıyor tabi hatasini.

\section{- Terbiye kelimesi ile eğitim kelimesi arasında ne fark var?}

- Prof. Dr. Zeki Arslantürk: Terbiye kelimesi "Rab" kelimesinden geliyor, Rablaştırma. Aynı zamanda din eğitimini de ihtiva ediyor ve aynı zamanda hem eğitimi hem de öğretimi kapsıyor. Tek başına eğitim kelimesi ile terbiyenin verdiği manayı ifade edemiyorsun. Onun için bizim eğitim sistemimizin sekülerleşmesi olayıdır bu. Öyle bir eğitim sistemi ki, dindarıyla dinsiziyle vatan haini yetiştiriyor. Bu eğitim sistemi tartışmalıdır.

Ortaçağdan önce düşüncenin merkezinde Tanrı vardır. Bu daha sonra insan merkezli bir düşünceye dönüşüyor. Aslında bu, daha önceden kalan bir felsefi alışkanlık. Ta Septiklerden gelen bir felsefi düşünce. Septiklerle yani şüpheciler diyebileceğimiz Grek felsefesinin bir ekolü var. Aslında ilk felsefe de onlardan başlıyor. Onlar hem epistemolojik açıdan hem ontolojik açıdan, hem varlık açısından hem bilgi teorisi açısından kesin hiçbir şeyi kabul etmezler. Her şeyden şüphe ederler. Ontolojik olarak şüphe edildiği vakit, Tanrı' dan da şüphe ederler. Tanrı' nın yerine insanı koydukları vakit, insan mutlak bir varlık değil, o zaman o mutlak olmayan varlığın davranışları da mutlak değil. Çünkü septiklere göre gittiğiniz her yönde farklı farklı hakikatler var. O zaman hakikatin ölçüsü tek değildir. Tanrıyı hakikatin tek ölçüsü kabul etmiyorlar. Onun yerine insanı koyuyorlar. Hümanizm, insancıllık anlamına gelen bir kavram değildir. Tanrının yerine insanı koyan bir felsefenin ifadesidir.

\section{- Hocam o zaman "Ben Hümanist bir insanım" demek "ben insanları çok severim" anlamına gelmiyor.}


- Prof. Dr. Zeki Arslantürk: Hayır, o anlama gelmez. Felsefe anlamında Tanrı mı, insan mı? Onun için din-felsefe arasındaki çekişme buradan doğuyor. Bunların karşısında Socrates vardır mesela. O da insanı merkeze koyar; ama amacı insanı ön plana çıkararak onu tanımlamaktır. Socrates, Atina’nın Tanrılarıyla savaşmıştır, Tanrıyla değil. Politeist Tanrı inancıyla savaşmıştır; çünkü hemen onun ardından gelen takipçilerinden Eflatun ve Aristo, düşüncenin ve toplumun merkezine Tanrıyı yerleştirirler.

Fındıkoğlu Hoca' dan geldik buraya. Hocaya göre terbiye asıldır, eğitim kelimesini kullanmaz; çünkü eğitim, yontma, eğme, büzme ve bir kalıba sokma anlamlarına gelir.

- Neye göre yontulacak öğrenci, hangi kalıba göre?

- Prof. Dr. Zeki Arslantürk: Eğer ölçün Rableştirme ölçüsü, milli kültür ölçüsü ise hoca orda terbiyeyi kullanmayı tercih eder.

- Mehmet Eröz Hoca sizi, tezinizle ilgili Amiran Hoca’ya yönlendirdi, sonra ne oldu?

- Prof. Dr. Zeki Arslantürk: Sonra Amiran Hoca'nın yanına oturdum. "Tezinin konusu ne?" dedi. Naima tarihi dedim. "Kolay" dedi, aldı eline kalemi üç tane başlık yazdı. "Bu üç başlığın altını doldur gel." dedi.

\section{- Naima döneminin önemli bir vakanüvisti değil mi?}

- Prof. Dr. Zeki Arslantürk: Tabi tabi! Naima'nın vefatı 1716. Önemli bir vakanüvist, yani tarih yazıcısı. O dönem kadar bireysel tarih yazmaları var. Ancak padişahlar sonraları kendi dönemlerini yazmaları için resmi kâtipler görevlendirdiler.

Naima, sivri dilli ve iğnelemeyi çok iyi yapan bir kişiliktir. Halep Türkmen'idir kendisi. Enfes bir Türkçesi vardır. Çekiştiği, geçinemediği ve eleştirdiği kişiler vardır. Bu sebepten, sürgünler ve sıkıntılar çeker ama yazmaya devam eder.

- Naima, İbn-i Haldun'un tavırlar nazariyesini temel alıyor değil mi? Yani devletler doğar, büyür ve ölür. Osmanlının yavaş yavaş sonuna yaklaştığını düşünüyor ve buna çözümler bulmaya çalışıyor. Peki, Osmanlının çöküşü sizce ne zaman başladı?

- Prof. Dr. Zeki Arslantürk: Hastalık vücuda ne zaman girmiştir? Hastalık Fatih zamanında Çandarlı'nın idamıyla girmiştir vücuda. Gedik Ahmet Paşa Rum devşirmesidir. Çandarlı Paşa ile arasında bir rekabet vardır. Bu rekabet İstanbul'un fethi sırasında iyice ortaya çıkar. Çandarlı Halil Paşa'nın o dönem İstanbul'un işgalinin yapılmamasını istediği söylentileri vardır. Tabi söylentiler dönmeye başlar. Bizans ile anlaştı Paşa diye; hâlbuki böyle bir şey yok.

Başka bir tefrika noktası, Çandarlı Paşa divan başkanı. Nüfuzlu da bir kişiliktir. Türk töresinde her ne kadar padişahlık babadan oğula geçiyor ise de divanın onayı gerekir, bu bir töre. Çandarlı'nın padişahı devireceği ve yerine geçeceği söylentileri de yayılıyor. Çünkü her Türk'ün padişah olma hakkı var. 
Türklerde Oğuz boyu mukaddestir. Osmanoğulları Oğuz boyundan geldikleri için, padişahlığa en layık onlar görünür. Hâlbuki Çandarlı Paşa Oğuz boyundan değildir. Yani saltanat iddia etmesi zayıf bir olasılıktır.

Çandarlı'nın idamından sonra Gedik Ahmet Paşa Veziriazam oluyor ve devlet kesin suretle devşirmelerin eline geçiyor. Kanuni' den sonra ise asıl çöküş dönemi başliyor devletin. Hastalık iyice gün yüzüne çıkıyor. Cephelerde savaşlar kaybediliyor. Osmanlı bütçesi genelde savaş bütçesidir, ganimetlere dayalı. Bütçe açık vermeye başlayınca bu sefer iç vergiye yönelme başlıyor. Senede iki defa alınan vergiler sekize çıkarılıyor. Bu sefer de Anadolu isyanları patlak veriyor. Yani devletin bütün düzeni yavaş yavaş bozuluyor.

Kanuni döneminde on iki bin kişidir maaşlı asker sayısı. IV. Murat döneminde dört yüz yirmi bin kişiye çıkmıştır sayı. Hem gelirler düşüyor hem de sayı artıyor.

Naima bütün bunları gördüğü vakit, "Bütün sıkıntı kaht-1 ricaldedir." diyor yani adam kıtlığı. İş bilen, iş becerebilen kişidir kaht-1 rical. Sorunu çözecek adam arayışındadır Naima; ama böyle birini bulamaz.

\section{- Bir taraftan da Erzurum'da asistanlık yaptınız.}

- Prof. Dr. Zeki Arslantürk: Evet, Cahit Tanyol Hoca beni çok sevmesine rağmen İstanbul' da beni asistan olarak almadı. Erzurum'da Orhan Türkdoğan Hoca' ya asistan oldum. Üçüncü gününde beni çağırdı. Yanına gittim. "Sana üç tane vasiyetim var, bundan sonra benim varisim sensin. Bu üç vasiyeti yerine getireceksin, getiresin ki sıkıntıya girmeyesin.” dedi. "Bir, talebeyi şımartma. İki, bütün yüzler kalır, bütün sıfırlar geçer tarafsız hareket et. Üç, sınıfa girdiğin vakit bilimin değer yargılarıyla hareket et. Bütün inanç ve yargı değerlerini vestiyere as. Bilimin değer yargısı doğru ve yanlıştır.” Dedi. Tabi bizde mollalık da var, bir şey diyemedim; ama anladı o derdimi. "Evet, Zeki Bey evladım. Mutlak doğru Allah'ın doğrusudur. Doğruyu bulmak üzere yola çıkan bir tek ilimdir. Eğer ilim vasıtasıyla doğruyu bulduysan Allah'ın doğrusunu bulmuşsundur, korkma."

Birincisine pek fazla riayet edemedim, ikincisinde de aksaklıklarım oldu ama üçüncüsüne mutlak riayet ettim. O yüzden sınıfta ders anlatırken ben ne sevmeyi ne de sövmeyi kullanırım. Öğrencilerime de derim ki: "Bilim sevme ve sövme sanatı değildir. Doğruyla yanlışı ayırt edip doğrudan yana tavır koyma sanatıdır. Dolayısıyla sövecekseniz de sevecekseniz de çıkalım kampüsten dışarıya bakın o zaman, Zeki Hoca nasıl sövüyor veya nasil seviyor."

Erzurum da asistan iken yurt dışı imkanı oldu. 1980 ihtilalinin üçüncü günü Almanya'ya gittim. Öncesi var tabi, Erzurum'da iken doktorayı verdik. İki kişiyiz Emir Erden, şimdi Nevşehir'de dekan. $\mathrm{O}$ ve ben varım. O benden bir ay önce doktorasını verdiği için hak onun. Bir kadro var sadece. İşte burada arkadaşlığın örneğini görürsünüz. Dost sırtını güvenerek dönebileceğin kişi demektir. Emir Erden, Hoca'ya gidiyor ve benim yerime Zeki Bey gitsin diyor ve hakkından fedakârlık ediyor.

Evrakları hazırladım, İstanbul'a gittim, ihtilal oldu, üç gün her yer kapalı, sonrasında açıldı ve Almanya' ya gittim. 


\section{- Ya gitmeseydiniz de dursaydınız.}

- Prof. Dr. Zeki Arslantürk: Gitmeseydim de dursaydım başıma çok şey gelebilirdi. Allah bilir tabi. Yurt dışına çıktıktan bir buçuk sene sonra falan geri döndüm, her şey durulmuştu tabi o zaman. Ben zarar görmedim; ama sonradan diğer asistan arkadaşlar zarar gördüler.

\section{- Erzurum'dan sonra Ankara'ya Gazi Üniversitesi’ne geldiniz.}

- Prof. Dr. Zeki Arslantürk: Ankara' ya gelebilmek için bir buçuk sene bekledim. Herkes istiyor ama bir türlü çıkmıyor tayin. Rektör Şakir Akça Hoca da 1srarla istiyor, hâlbuki bir imzalık iş, takdiri ilahi, bir süre bekledik öyle.

Ankara'ya başladıktan altı ay sonra beni Bolu'ya gönderdiler, meslek yüksekokulu müdürlüğüne. Bolu' ya geldik bir tane oda, yurdun bir odası. Epey uğraştan sonra binayı falan yaptık. Sabah gelirdim işe, toplardım memurları hizmetlileri çay ocağında. Onlar köyden veya evden getirdiklerini ortaya koyarlardı ve beraberce yerdik, ondan sonra ne istersem yaparlard. Benim hayatımda idarecilik böyledir. O bahçeyi, o okulu hep beraber kan ter içinde yaptık.

Bir zaman sonra bir sicil affı çıktı. Gittim personel dairesine, dosyamı görmek istedim ama evraklar af nedeniyle imha edilmiş. Personel başkanına sordum, ne vardı benim dosyada diye. Meğer benim dosya epey kabarıkmış. Yine orada öğrendim, meğer benim tayinimin asıl nedeni bu dosya imiş. "Bu dosyalar falan olmasaydı, Şakir Hoca seni almazdı.” dedi personel başkanı bana.

\section{- 1995 ylında İstanbul'a geri dönüyorsunuz.}

- Prof. Dr. Zeki Arslantürk: Evet, İstanbul'a Marmara İlahiyata geldim.

- Peki, buradan sonra ben eserleriniz üzerinden devam etmek istiyorum. “Kutsalın Dönüşü" kitabınızı konuşmak istiyorum. Kutsalın dönüşü derken, dinin tekrardan yükselişe geçmesini mi kastediyorsunuz?

- Prof. Dr. Zeki Arslantürk: Benim bütün kitaplarım Erzurum'da planlanmış, kitaplarımın müsveddeleri hazırlanmıştır. Benim doktora tezim, demin bahsettik, Naima' ya Göre Osmanlı'nın Çöküş Sebepleri. İki baskı yaptı. Ondan sonra Sosyal Bilimciler İçin Araştırma Metot ve Teknikleri kitabım var. Bunun birçok baskısı var. Son iki baskıda adı, Uygulamalı Sosyal Araştırmalar oldu. Bir de Sosyolojide Temel Kavramlar ve Kuramlar var. O da yedi-sekiz baskı yaptı. Yurt dışında altı üniversitede okutuluyor. Temel özelliği şudur: Milli sosyolojiye bir nefestir. Bunun da kaynağı yine Fındıkoğlu Hoca'dır. Taklitten ârî bir Türk sosyolojisi oluşturma ideali. Ne kadar olmuştur bilemem ama eleştirilere baktığımızda olumlu dönüşler alıyoruz. Onun üzerine Din Sosyolojisi Dersleri diye aynı konuları din sosyolojisine uyarlamak üzere ele aldım ve epey yol aldım. Yakında o da biter inşallah.

Bir tek “Kutsalın Dönüşǖ” Erzurum menşeli değil. O da Bolu’da ortaya çıktı. Bolu'da Türk gençlerinin din algılayışları üzerine yaptığım bir araştırmayı daha sonra Marmara Üniversitesine geldiğim vakit proje olarak verdim ve kabul edildi. Onun da iddiası şudur: 
Modernizmin madde merkezli dayatmasına karşı insanlar maneviyata yöneliyorlar, şeklindeki bir hipotezin testidir.

Benim görüşüme göre, 21. yüzyılda din yeniden insanların gündemine girmiş vaziyette: ama bu gündem klasik dinler şeklinde değil de yeni arayışlar, bu yeni arayışlarda kurgu dinler, kurgu mezhepler, Budizm ve İslam'ın tasavvuf mistik yapısı ön planda; çünkü batıya İslam'ın şeriat kısmı kalın geliyor. Daha çok ruhu tatmin edebilecek bir arayış içerisindeler; çünkü madde ruhu sıkıntıya sokuyor. Dolayısıyla İslam mistisizmi batıda revaçta.

- Türkiye'de kutsala dönüş̧ ne zaman başladı?

- Prof. Dr. Zeki Arslantürk: Mustafa Kemal aslında bir yoklar ülkesi devralmıştı. Madde de yok insan da yoktur. O yoklar ülkesinden bir devlet, bir toplum inşa edecektir. Elindeki malzeme ya hasarlı ya da kusurlu haldedir. Hasarlı malzemeyi ayıklayacak, kullanılmayanları atacak, yerine yenisini kuracak, bu aslında büyük bir olaydır. Hatası ve sevabı ile samimidir Mustafa Kemal. Kurduğu müesseseler de, devleti ayakta tutacak şekilde kurulmuştur. Milli devlet yaratmak idealindedir.

Daha sonra İnönü döneminde Helen kültürüne yöneliniyor. Helen kültürü hümanizma kültürüdür. Hümanizma kültürü nedeniyle de Türkiye'de epey bir din sıkıntısı yaşanıyor. Din yer altına iniyor. Din bir ihtiyaç, bu ihtiyacı ortadan kaldırmak mümkün değil. İnanç şu veya bu şekilde tezahür edebilir; ama inanma ihtiyacı insanda kaybolmaz; çünkü bir eğilimdir o. Yer altından yürüyen din son zamanlarda fırsatını bulup gün yüzüne çıktı; ama köstebek nasıl patatesi bulup gün yüzüne çıkıncaya kadar tarlayı perişan ederse, bu günkü dinî guruplar öyle bir durumdaki din tarlasını tanıyamıyoruz.

1997 yılında bir tez yaptırdım, Emniyet Müdürlüğü’nden bir öğrencime. Eminönü’nde suç oranları, durum ve sebepleriyle ilgili. $\mathrm{O}$ arada öğrencime sordum, ya sizde kaydı vardır dedim, İstanbul'da kaç tane şeyh var. Bir zaman sonra geldi ki meğer İstanbul'da sekiz binden fazla şeyh varmış, poliste kaydı olan. Sekiz bin tanesi sahte, küsurunu bulursanız elini öpeceğim. Var mı, var ama işte o sahte köstebekler yüzünden bulması çok zor.

Şeyhliğini herkes ilan edebilir. Yanına bir goygoycu buldu mu, katlanarak gider o. Bir bakıyorsunuz, piyasada bir sürü adamın etrafında binlerce kişi.

\section{- Din Sosyolojisine yönelmenizde bunların etkisi oldu mu?}

- Prof. Dr. Zeki Arslantürk: Din sosyolojisini seçmedim ben aslında. Benim asıl alanım genel sosyoloji ve metodolojidir. Bolu'dan İstanbul İlahiyata geldiğim vakit ne yapacağım, din sosyolojisi tabi. Yani bu şekilde din sosyolojisine yöneldim.

Din sosyolojisi yaparken bir yandan dini, diğer taraftan da sosyolojiyi iyi bilmen lazim.

\section{- Din sosyolojisi İslam ümmetinin sorunlarına çözüm bulabilir mi?}

- Prof. Dr. Zeki Arslantürk: Ben ilahiyattaki öğrencilerime, bu ümmetin problemlerini anlama ve açıklamada sosyolojiden faydalanabileceğimizi üç ayda zor 
anlatıyorum. Üç ay sonra da başımın etini yiyorlar. Yüksek lisans ve doktoralarda en fazla müracaat alan anabilim dalı oluyor ondan sonra.

- Peki Sosyolojinin amacı, sadece problemi tespit etmek midir?

- Prof. Dr. Zeki Arslantürk: Hayır, hayır. Bilimin amacı birinci derecede anlama ve açıklamadır. Sonra faklı bilim dalları bu verileri kullanırlar. Son dönemde en büyük bilim felsefecisi olarak kabul edilen Immanuel Wallerstein' ın "Sosyal bilimleri açalım.” diye bir tezi var. Artık sosyal bilimlerin birbirinden kopuk olması geneli anlamada yeterli olmuyor. Kopukluk oluyor. Dolayısıyla önce geneli bir anlayalım ondan sonra özele inelim. Bu da zaten metodolojik bir problem.

- Sosyologun üslubu nasıl olmalı ve ideolojiye nasıl yaklaşmalıdır?

- Prof. Dr. Zeki Arslantürk: Üslup araştırma yaparken üçüncü şahıs olmayı anlatmaktır. Araştırma yapanlara bakıyoruz, hemen kişi devreye giriyor, taraf tutar gibi. Benim doçentlik çalışmam ilkinde kabul edilmedi. Sebeplerinden biri, tezimde "ne yazık ki" diye bir kelime kullanmışım. Bilim adamının üslubu bu olamaz diye reddettiler. O nedenle biz bilimin; doğruyu tespit, gözlediğini anlama ve açıklama metodolojisini kullandığımız vakit, üslubumuz da bilimin kullandığı üslup olmalı. İşte ideoloji ve üslup arasındaki ilişki de orada. Eğer bir ideolojiyi ön plana çıkarıyorsak üslubumuz o ideolojinin üslubudur diyoruz. Din bir ideoloji değildir; ama dinin bir ideolojik yanı vardır. Ben dindar olabilirim ama amacım doğruyu tespit, gözlediğimi anlatmak olduğuna göre, gözlediğimi doğru anlattığımda, doğruyu da bulduğum zaman, sosyoloji diğer bilimlere pas verir.

- Sosyolojinin Türkiye'ye gelişinden beri bu ideoloji-bilimsellik kıvamını tutturamadık mı?

- Prof. Dr. Zeki Arslantürk: Tutturamadık tabi.

- İdeolojiye mi kayıveriyor hemen?

- Prof. Dr. Zeki Arslantürk: İdeolojiye kayıyor, yani bana gelen dosyalara bir bakıyorum, yaa diyorum bu vaiz üslubu. Biz vaiz üslubunu kullanamayı.

- Yine dünkü Çalıştayda uygulamalı sosyoloji, teorik sosyoloji konusu vardı. Bir sosyolog bunlardan birini seçmek zorunda mıdır?

- Prof. Dr. Zeki Arslantürk: Hayır. Her ikisini de birlikte kullanması gerekiyorsa ikisini birlikte kullanması lazım. Yani hem nicel, hem de nitel araştırmayı birlikte kullanmak gerekiyor. Nitel araştırmada zaten antropolojinin de konusu içine girer. Sosyolojinin katı, pozitif metotlarının yetersiz olduğu bugün zaten ortaya çıkmış vaziyette. Antropolojinin metotlarını, anlama, sezme, arka planı tahmin, katılımlı gözlem metotlarında kullanmak suretiyle doğru bilgiye daha rahat varabiliriz.

- Çalıştayda öğleden sonraki oturumda sosyologların iş bulma konusunda çektikleri sıkıntılar ele alındı. Bu konuda siz neler söylemek istersiniz?

- Prof. Dr. Zeki Arslantürk: O konuda ben konuşmadım; çünkü ben uzun zamandır sosyoloji bölümünde değilim. Dolayısıyla bu konuda fazla bir malumatım yok; ancak şunu 
söyleyebilirim, ben eğitimde iki tanımı öne çıkarırım: Birisi Max Weber'in tanımıdır, diğeri de Rudolf Steiner'in tanımıdır. Weber'in tanımı şöyle: Eğitimin temel amacı kişinin daha sonra gelmeyi arzu ettiği pozisyona önceden hazırlanması işlemidir. $\mathrm{O}$ zaman burada birinci derecede biz sosyoloji öğrencileri için bir hedef göstermeliyiz ve hedefi tarif etmeliyiz ki ögrenci o hedefi arzu edip etmeyeceğini bilsin.

\section{- Hedeften kastınız nedir?}

- Prof. Dr. Zeki Arslantürk: Yarın nereye geleceğini, ne işler yapacağını göstermemiz lazım ki, öğrenci desin ki ben bu işi yaparım veya yapamam. Bizim o hedefi çoğaltmamız ve öğrenciyi motive etmemiz lazım. Başarı beklentiye göredir. Beklentisi düşük olan objelere yaklaşma veya onunla ilgili davranışların başarısı düşüktür.

Dün o ilahiyat kökenli olanların sosyoloji bölümlerini işgal ettikleri tartışmasını bu bağlamda ele almak lazım. Bizim öğrencilerimiz buna hevesli çünkü hedefleri belli. Biz de bu dersleri onların kafalarını, ufuklarını açmak için kullanıyoruz. Ufku kapalı olan insanın düşüncesi Taliban düşüncesidir. Bu nedenle İlahiyatçllardan çekinen o hocalara, bizim yetiştirdiğimiz çocukların düşündükleri gibi olmadığını söyledim.

Weber'i söyledik, unutmadan Steiner'in tanımını da söyleyelim. Önceden belirlenmiş kurallar çerçevesinde kişiye davranış kazandırma, davranış geliştirme, davranış değiştirme süreci ve olgusudur. Bizim sorunumuz burada işte. Önceden belirlenmiş kurallarımız yok. Her kafadan bir ses çıkıyor. Ee! Hangi davranışı kazandıracağız biz bu çocuklara da Weber'in dediği gibi pozisyonlara yönlendireceğiz? Elimizde bir müktesebat envanteri yok. Herkes bir müfredat yapıyor, bir bakıyorsunuz birbirinden değişik programlar. Benim orada vurgulamak istediğim de oydu zaten. Hiçbir programda din sosyolojisi yok. Nasıl olacak bu iş?

- Son olarak şunu da sorayım. Sosyoloji lisans ve yüksek lisans öğrencilerine neler tavsiye edersiniz?

- Prof. Dr. Zeki Arslantürk: Sosyoloji bir hevestir. İlim, zaten bir heves, meraktır. Sosyoloji ise bu merakın toplumsal tarafıdır yani toplumu merak etmektir. İşte o merakı gidermek için biz yüksek lisansa talebe alırken ilk sorumuz odur. Neden din sosyolojisi, merakınız nereden doğdu, bu merakı gidermek için neler yaptınız, neler okudunuz? Bu cevabı aldıktan sonra zaten ben diğerlerini fazla araştırmıyorum. Merakın da gereği yapıldı mı? O da önemli. Meraklısına kapım her zaman açıktır.

- Hocam bize zaman ayırıp sorularımızı cevaplandırma lütfunda bulunduğunuz için çok teşekkür ederiz. 